\title{
The effect of multiple sclerosis on the professional life of a group of Brazilian patients
}

\author{
Yára Dadalti Fragoso', Alessandro Finkelsztejn², \\ Maria Cristina B. Giacomo ${ }^{3}$, Liliana Russo ${ }^{3}$, Wesley Soares Cruz ${ }^{4}$
}

\begin{abstract}
Objective: To assess the impact of multiple sclerosis (MS) on the professional life of Brazilian patients. Method: One hundred MS patients were randomly selected from the database of the Brazilian Multiple Sclerosis Association (ABEM). An individual interview was carried out by telephone by a member of ABEM, who collected data on the patients' clinical status, educational level and professional lives. Results: Complete data were obtained from 96 patients ( 27 males and 69 females) aged 55.0 \pm 14.1 years, with average disease duration of $4.6 \pm 4.0$ years). Eighty percent had eleven or more years of schooling. Among the whole group, $66 \%$ did not present limitations on walking. The longer the disease duration and the older the patient were, the higher the chances were that the patient was retired or receiving workers' compensation benefits. However, even among patients with MS for less than five years, the rate of non-participation in the workforce was $47.7 \%$. Fatigue, paresthesia, cognitive dysfunction and pain were often cited as the motives for not working. Conclusion: MS patients presented high levels of unemployment, retirement and receipt of workers' compensation benefits, despite their high schooling levels. Age, disease duration and disability influenced these results for the whole group. However, even among younger patients with shorter disease duration and low disability, this finding remained.
\end{abstract}

Key words: multiple sclerosis, work, retirement, economics.

\section{O efeito da esclerose múltipla na vida profissional de um grupo de pacientes brasileiros}

\section{RESUMO}

Objetivo: Avaliar o impacto da esclerose múltipla (EM) na vida profissional de pacientes brasileiros. Método: Cem pacientes com EM foram aleatoriamente selecionados da base de dados da Associação Brasileira de Esclerose Múltipla (ABEM). Uma entrevista individual por telefone foi realizada por um membro da ABEM que obteve dados sobre a condição clínica e a vida educacional e profissional dos pacientes. Resultados: Dados completos foram obtidos de 96 pacientes ( 27 homens, 69 mulheres; idade 55,0 14,1 anos com um tempo médio de doença de $4,6 \pm 4,0$ anos). Oitenta por cento deles tinham onze ou mais anos de estudo. Do grupo total, 66\% não apresentavam limitações para deambular. Quanto maior o tempo de doença e quanto mais velho o paciente, maior a chance que estivesse aposentado ou recebendo auxílio financeiro por afastamento. No entanto, mesmo os pacientes com menos de cinco anos de EM tinham um índice de ausência da força de trabalho de 47,7\%. Fadiga, parestesias, alterações cognitivas e dor foram frequentemente citadas como causas para não estar trabalhando. Conclusão: Pacientes com EM têm um alto índice de desemprego, aposentadoria e afastamento do trabalho apesar da alta escolaridade. Idade, duração da doença e incapacidade influenciaram estes achados. No entanto, estes resultados se mantiveram mesmo em pacientes mais jovens com menor tempo de doença e pouca incapacidade.

Palavras-chave: esclerose múltipla, trabalho, absenteísmo, economia. 
Multiple sclerosis (MS) affects young and middleaged individuals and leads to a variety of disabilities that can alter their daily routines. The disease may progress with motor, sensory, visual and coordination deficits, demanding special adjustments of the environment for patients to proceed with their activities. Acute MS relapses may require hospitalization and the symptoms may take weeks to improve. Fatigue, depression, cognitive dysfunction and chronic pain may render patients incapable of performing daily tasks, even in the absence of motor disability. Therefore, the burden of the disease cannot be understood only in terms of the number of relapses or the level of disability according to fixed measurement scales. MS patients may have severe impairment of their ability to work, and this has not been considered in any previous Brazilian study.

Few studies have taken into consideration the effect of MS on patients' working lives. In fact, MS tends to strike at the time when individuals are starting their professional lives, and/or during the final years of schooling. The investment in education for a profession is immeasurable, since it does not include only the school fees, books and time invested. The shattering effects on financial planning cannot be measured, despite recognition that the losses are large.

Studies assessing employment parameters among MS patients have only been conducted recently, and they are mainly concentrated in European countries ${ }^{1-11}$ and the $\mathrm{USA}^{12}$. The results are very similar across the studies, showing that $20-45 \%$ of the patients were not working (unemployed, retired or receiving workers' compensation benefits) after the initial five years of MS. This number increased to 78-96\% after ten years of the disease. These data on the cost and burden of the disease were obtained from Denmark ${ }^{1}$, Belgium ${ }^{2}$, Holland ${ }^{3}$, Austria ${ }^{4}$, United Kingdom ${ }^{5}$, Switzerland ${ }^{6}$, Italy ${ }^{7}$, Spain $^{8}$, Germany ${ }^{9}$, France $^{10}$, Sweden ${ }^{11}$ and the USA ${ }^{12}$. The decrease in gross income following early retirement had a significant impact both on the patients (and their families) and on society.

The aim of the present work was to assess the impact of MS on Brazilian patients' professional lives.

\section{METHOD}

The Brazilian Multiple Sclerosis Association (ABEM) is an independent non-profit institution that assists patients on educational and legal matters relating to MS. Thus, ABEM has a large database on MS patients, and this was used for the present study.

This study was approved by the UNIMES Ethics Committee, under the number 005/10. All participants were contacted by telephone and only those who volunteered to participate were enrolled. The Ethics Committee waived the requirement for patients' written informed consent with their signature because of the study design (assessment over the telephone). Patients were not identified in any way, either by name or by initials, in accordance with the recommendations of the Ethics Committee.

Upon registering in ABEM, all patients with MS give an initial formal consent to participate in studies carried out over the telephone.One hundred telephone numbers from patients registered in ABEM were randomly selected by an independent member of the institution. The numbers were drawn from the ABEM database, without any criteria for inclusion of patients, characterizing a purely randomized selection. Data on gender, age, educational level, profession and working status were collected. Patients who had retired after completion of the expected full number of working years were excluded. MS duration, disability, symptoms and limitations were all recorded at the time of the telephone interview. Data were registered in an Excel file specially designed for this project.

Mean values and standard deviations (SD) were used for continuous variables. The $t$ test was used to assess the significance of differences. The degree of linear agreement between parameters was calculated using the Pearson correlation coefficient. All statistical analyses were performed using SPSS v 13.0.

\section{RESULTS}

Out of the 100 telephone calls answered by the patients, 96 of them provided full data for analysis. The assessed population comprised 27 males and 69 females aged 55.0 \pm 14.1 years (range 17 to 65 years), with average disease duration of $4.6 \pm 4.0$ years. Except for one young student (17 years old) and one housewife with no previous working experience (both of them without major MS-related complaints), all other patients were or had been working.

From the group of 96 patients, 64 had no limitations on walking; 27 had variable degrees of walking limitations (10 of them making use of a cane, even if only occasionally); and five were restricted to double support for short walks or a wheelchair, or were bedridden.

Regarding schooling, 19 patients had had eight years of formal education or less, 29 had up to eleven years of schooling and 48 had finished university. The average duration of formal schooling for this group of MS patients was 12.4 years. Many of them had also attended language courses and technical or specialization courses that were not taken into account here.

Thirty-nine patients (40.0\%) were working and/or studying regularly, including the abovementioned housewife and young student. Their average age was $39.5 \pm 6.3$ years. Thirty-seven patients (38.5\%) were not working, and were receiving workers' compensation benefits due to the disease. Their average age was $41.0 \pm 10.4$ years. These 
two populations were not significantly different from each other regarding age, gender, disability or schooling.

Twenty patients had retired prematurely due to MS. They were significantly older $(55.0 \pm 14.1$ years) than patients who were regularly working $(\mathrm{p}<0.0001)$; had had the disease for a significantly longer time $(7.7 \pm 5.0$ years; $\mathrm{p}=0.003)$; and presented greater disability than did the working patients. Thirteen (out of these twenty patients) were constantly in need of support for walking, or a wheelchair, or were bedridden. They did not differ significantly from the working patients regarding gender and schooling.

With regard to disease duration, 65 patients reported that they had had MS for less than five years, and 31 (47.7\%) of them remained at work. Thirty-one patients said that they had had MS for more than five years, and seven $(22.6 \%)$ of them remained at work. There was a significant negative correlation between disease duration and working regularly $(\mathrm{p}<0.001)$. Of the above group with MS for longer than five years, 12 patients had had MS for more than 10 years. Eleven of them were not employed. Only one female patient with MS for more than 10 years worked informally, as a private teacher.

Among the reasons for not working, the patients mentioned fatigue, paresthesia, cognitive dysfunction and chronic pain as very frequent causes. In fact, most patients (95.8\%) had at least three of these complaints, independently of disease duration and/or physical disability.

Fifty-eight patients $(60.4 \%)$ said that they lived on their own, in a house or apartment that they owned fully. Eight patients (8.3\%) were still paying off mortgages.

\section{DISCUSSION}

MS is a chronic disease that affects mainly young adults. The costs of diagnosing and treating MS are fully covered by the Brazilian Health Authorities, and include consultations, hospitalization, laboratory tests, imaging examinations and extensive differential diagnosis testing, along with all formulations of beta-interferon and glatiramer acetate. Despite unclear data on these direct and indirect costs of MS in Brazil, data from around the world show that this investment is of the order of thousands of dollars per patient per year ${ }^{13}$.

The personal cost of MS is more difficult to assess. Young adults who were investing in their careers may have to adapt to drastic changes due to neurological disabilities or to MS symptoms. These changes may range from small adaptations at work to important modifications caused by impaired mobility and dependence on caregivers $^{14,15}$. Fatigue, impaired cognition, neurological, psychological and overall symptoms, relapses requiring hospitalization and absenteeism among such patients may render the working environment not adaptable to their needs. A recent study carried out in the United States showed that MS poses a significant burden on employers, with indirect costs due to absenteeism and disability requirements for these patients at work of more than US\$ 4,000 per patient per year ${ }^{16}$. In Canada, MS patients over the age of 39 years who are still employed are at risk of becoming unemployed in the next 2.5 years ${ }^{17}$. Patients with greater severity of disabilities due to MS were more likely to be unemployed in the United Kingdom than were those with fewer disabilities ${ }^{18}$. More than a quarter of MS patients in the USA are seriously worried that they may not be able to afford their basic necessities (housing and food $)^{19}$. Ultimately, the increasing risk of cessation of employment over time may force patients into early retirement ${ }^{20}$ and life changes ${ }^{21}$. Despite the lack of similar studies in Brazil, it is not unreasonable to assume that MS patients in our country present similar findings. The high rates of retirement and receipt of workers' compensation benefits due to MS may reflect what may simply be seen as a guarantee of some monthly income. However, even with the guaranteed income, the impact of being out of the workforce may negatively reflect on family life, further adding to the burden of $\mathrm{MS}^{22,23}$.

The present study focused on a random sample of Brazilian patients. It was noteworthy that the schooling level among these patients was high, which reinforces the idea that individuals of higher socioeconomic levels have greater access to diagnosis, treatment and ABEM registration. New health programs for earlier diagnosis among populations of lower socioeconomic level may start to change this picture. However, the fact that half of the present study population had university degrees made it possible to reach interesting conclusions regarding the effect of MS on employment. Typically, these individuals had invested a significant amount of time, money and other resources towards a career that they may never see flourish. They were young and had, in general, less than five years of disease, with typically low disability. When the economic burden of MS is considered, the impact on patients, their families and society is immense. When the personal burden of MS is considered, as was done in the present paper, the burden is immeasurable.

\section{REFERENCES}

1. Pfleger CC, Flachs EM, Koch-Henriksen N. Social consequences of multiple sclerosis (1): early pension and temporary unemployment - a historical prospective cohort study. Mult Scler 2010;16:121-126.

2. Kobelt G. Costs and quality of life for patients with multiple sclerosis in Belgium. Eur J Health Econ 2006;7(Suppl 2):S24-S33.

3. Kobelt G, Berg J, Lindgren P, et al. Costs and quality of life in multiple sclerosis in The Netherlands. Eur J Health Econ 2006;7(Suppl 2):S55-S64

4. Kobelt G, Berg J, Lindgren P, Kerrigan J, Russell N, Nixon R. Costs and quality of life of multiple sclerosis in the United Kingdom. Eur J Health Econ 2006;7(Suppl 2):S96-S104.

5. Kobelt G, Berg J, Lindgren $P$, et al. Costs and quality of life of multiple sclerosis in Austria. Eur J Health Econ 2006;7(Suppl 2):S14-S23.

6. Kobelt G, Berg J, Lindgren P, Gerfin A, Lutz J. Costs and quality of life of mul- 
tiple sclerosis in Switzerland. Eur J Health Econ 2006;7(Suppl 2):S86-S95.

7. Kobelt G, Berg J, Lindgren P, Battaglia M, Lucioni C, Uccelli A. Costs and quality of life of multiple sclerosis in Italy. Eur J Health Econ 2006;7(Suppl 2): S45-S54.

8. Kobelt G, Berg J, Lindgren P, et al. Costs and quality of life of multiple sclerosis in Spain. Eur J Health Econ 2006;7(Suppl 2):S65-S74.

9. Kobelt G, Berg J, Lindgren P, et al. Costs and quality of life of multiple sclerosis in Germany. Eur J Health Econ 2006;7(Suppl 2):S34-S44.

10. Kobelt G, Texier-Richard B, Lindgren P. The long-term cost of multiple sclerosis in France and potential changes with disease-modifying interventions. Mult Scler 2009:15:741-751.

11. Henriksson F, Fredrikson S, Masterman T, Jönsson B. Costs, quality of life and disease severity in multiple sclerosis: a cross-sectional study in Sweden Eur J Neurol 2001;8:27-35.

12. Kobelt G, Berg J, Atherly D, Hadjimichael O. Costs and quality of life in multiple sclerosis: a cross-sectional study in the United States. Neurology 2006;66:1696-16702.

13. Namaka M, Turcotte D, Leong C, Grossberndt A, Klassen D. Multiple sclerosis: etiology and treatment strategies. Consult Pharm 2008;23:886-896.

14. Sutliff MH. Contribution of impaired mobility to patient burden in multiple sclerosis. Curr Med Res Opin 2010;26:109-119.

15. McCabe MP, O'Connor EJ. A longitudinal study of economic pressure among people living with a progressive neurological illness. Chronic Illn 2009;5:177-183.

16. Ivanova Jl, Bimbaum HG, Samuels S, Davis M, Phillips AL, Meletiche D. The cost of disability and medically related absenteeism among employees with multiple sclerosis in the US. Pharmacoeconomics 2009;27:681-691.

17. Busche KD, Fisk JD, Murray TJ, Metz LM. Short term predictors of unemployment in multiple sclerosis patients. Can J Neurol Sci 2003;0:137-142.

18. O'Connor RJ, Cano SJ, Ramio I, Torrenta L, Thompson AJ, Playford ED. Factors influencing work retention for people with multiple sclerosis: cross-sectional studies using qualitative and quantitative methods. J Neurol 2005;252:892-896.

19. lezzoni LI, Ngo L. Health, disability, and life insurance experiences of working-age persons with multiple sclerosis. Mult Scler. 2007;13:534-546.

20. Julian LJ, Vella L, Vollmer T, Hadjmichael O, Mohr DC. Employment in multiple sclerosis: exiting and re-entering the work force. J Neurol 2008;255: 1354-1360.

21. Lexell EM, Lund ML, Iwarsson S. Constantly changing lives: experiences of people with multiple sclerosis. Am J Occup Ther 2009;63:772-781.

22. Bogosian A, Moss-Morris R, Yardley L, Dennison L. Experiences of partners of people in the early stages of multiple sclerosis. Mult Scler 2009;15:876-84.

23. Starks H, Morris MA, Yorkston KM, Gray RF, Johnson KL. Being in- or outof-sync: couples' adaptation to change in multiple sclerosis. Disabil Rehabil 2010;32:196-206 